\title{
Meningkatkan Kewaspadaan Masyarakat Terhadap COVID-19 pada Masa PPKM di Kelurahan Cibodasari
}

\author{
Dabella Yunia, Nada Shafa Soraya Gandakusumah, Nina Safitri Zahra, Musdalifah, Farlina \\ Fajrianti, Haikal Diarahmana Putra, Firhani Ashri, \& Itta Qunnisa \\ Universitas Sultang Ageng Tirtayasa,Indonesia
}

\begin{abstract}
The Covid-19 pandemic has hit Indonesia since March 2020 until now. All components of the Indonesian state must unite to overcome the pandemic. One of the tangible forms of community service from Sultan Ageng Tirtayasa University is to increase public awareness of Covid-19 during the Enforcement of Restrictions on Community Activities in Cibodasari Village. Community service activities carried out include socializing covid-19, spraying disinfectants, and socializing the Enforcement of Restrictions on Community Activities. The activity was carried out in a hybrid manner by implementing a strict health protocol. The result of the implementation of these activities is that the residents of the Cibodasari sub-district are increasingly aware of Covid-19 so that the discipline in applying health protocols is felt, the wider impact is felt at the Tangerang City level by decreasing the level of the Bed Occupancy Ratio.
\end{abstract}

Keywords: Covid-19, Socialization, Spraying Disinfectants, Enforcement of Restrictions on Community Activities

\section{Pendahuluan}

Pandemi Covid-19 melanda Indonesia sejak Maret 2020. Hal ini menyebabkan banyak masyarakat yang menjadi terjangkit covid-19, bahkan sampai meninggal. Data Kementrian Kesehatan per tanggal 31 Juli 2021 menunjukkan bahwa 3.409.658 terkonfirmasi positif Covid-19, sebanyak 2.770.092 sembuh dan korban meninggal sebanyak 94.119 jiwa. Berdasarkan data tesebut maka diperlukan kepedulian setiap individu untuk menjaga kesehatan untuk menghindari korban jiwa akibat covid-19 (https://covid19.tangerangkota.go.id/).

Selain di tingkat pusat langkah penanggulangan juga dilakukan oleh pemerintah daerah dengan menyiagakan rumah sakit beserta tenaga kesehatan. Pemberlakuan PPKM Berbasis Mikro dalam rangka meningkatkan kewaspadaan masyarakat di tingkat Desa/Kelurahan terhadap penyebaran Corona Virus Disease 2019 (Covid-19). Sehingga perlu peranan tingkat Desa/Kelurahan dalam Pemberlakuan Pembatasan Kegiatan Masyarakat Berbasis Mikro. Selain itu, Pergub Nomor 7 Tahun 2021 juga untuk melaksanakan ketentuan Pasal 7 Peraturan Daerah Provinsi Banten Nomor 1 Tahun 2021 tentang Penanggulangan Corona Virus Disease-19.

Kelurahan Cibodasari berada di Kecamatan Cibodas, Kota Tangerang, Provinsi Banten, Indonesia. Kelurahan Cibodasari merupakan 1 dari 6 kelurahan yang berada di wilayah Kecamatan Cibodas. Kelurahan Cibodas merupakan salah satu kelurahan dengan tingkat konfirmasi positif covid-19 dengan jumlah cukup banyak. Berdasarkan data yang diperoleh dari https://covid19.tangerangkota.go.id/ pada tanggal 8 Agustus 2021 bahwa suspect aktif dirawat sebanyak 42 orang, konfirmasi total 946, konfirmasi dirawat sebanyak 138, konfirmasi sembuh 795 dan meninggal sebanyak 13 jiwa.

Corresponding author:

E-mail address: dabellayunia@untirta.ac.id 
Perkembangan Kasus Covid-19 masih menunjukkan peningkatan yang eksponensial, baik di Kelurahan Cibodasari maupun di daerah lain, baik di Kota Tangerang maupun di luar Kota Tangerang bahkan se-Jawa-Bali. Untuk itu, pemerintah mengambil langkah cepat dengan melakukan sejumlah langkah antisipatif agar jumlah peningkatannya dapat segera dikendalikan. Seluruh Jawa dan Bali diberlakukan PPKM Darurat sejak Tanggal 3 Juli 2021-20 Juli 2021, langkah ini diambil pemrintah untuk mengendalikan mobilitas masyarakat guna menekan Covid-19.

Tingginya kasus terkonfirmasi covid-19 menurut pakar epidemiologi Universitas Diponegoro (Undip), Prof. Suharyo Hadisaputro ada tiga faktor utama yaitu masyarakat tidak sepenuhnya melakukan kegiatan untuk memenuhi protokol kesehatan (prokes), kemudian varian Delta yang menyebar lebih masif dibandingkan varian lainnya, dan vaksinasi yang belum memadai sehingga kekebalan komuniti belum bisa diharapkan (https://www.undip.ac.id).

Pengendalian Covid-19 pada kelurahan Cibodasari selain diatur pemerintah juga harus muncul dari kesadaran masyarakat sendiri. Masih kurangnya kesadaran masyarakat mematuhi protokoler kesehatan menjadi salah satu penyebab sulitnya memutus rantai penularan Covid-19 di Kelurahan Cibodasari. Sikap kurang peduli sebagian warga masyarakat mematuhi protokol kesehatan, khususnya 3M (memakai masker, mencuci tangan pakai sabun di air mengalir dan menjaga jarak) membuat angka kasus Covid-19 di negara kita terus meningkat.

Salah satu pemicu masih tingginya Covid-19 adalah sikap apatisme warga masyarakat terhadap bahaya dan pencegahan Covid-19, yaitu rasa tidak percaya bahwa Covid-19 benar-benar ada dan rasa yakin bahwa dirinya tidak akan bisa tertular Covid-19. sikap apatis tentang bahaya Covid-19 tersebut membuat orang enggan mematuhi protokol kesehatan Covid-19. Ketidak-pedulian warga masyarakat terhadap 3M dan melakukan isolasi mandiri membuat potensi penularan Covid-19 di masyarakat akan tetap tinggi seperti terjadi di beberapa negara besar. Berdasarkan latar belakang tersebut, artikel ini bertujuan untuk meningkatkan kewaspadaan masyarakat terhadap Covid-19 di Kelurahan Cibodasari.

\section{Metode}

Pengabdian kepada masyarakat ini dilakukan dengan beberapa kegiatan yang dilakukan secara hybrid. Kegiatan pengabdian kepada masyarakat ini melibatkan warga Kelurahan Cibodasri, Mahasiswa dan Dosen Universitas Sultan Ageng Tirtayasa. Kegiatan yang dilakukan meliputi Sosialisasi Covid-19, Penyemprotan Disinfektan, dan Sosialisasi PPKM.

1. Sosialisasi Covid-19 (secara daring dalam entuk pamflet dengan memanfaatkan platform instagram dan youtube) adalah agar masyarakat warga Kelurahan Cibodasari, dan masyarakat umum menyadari dan paham pentingnya menerapkan pola hidup sehat dan mentaati protokol kesehatan demi menekan penyebaran wabah Covid-19.

2. Penyemprotan disinfektan adalah agar masyarakat warga Kelurahan Cibodasari menjadi lingkungan yang bersih dan sehat sehingga dapat terhindar dari virus covid-19.

3. Sosialisasi aturan PPKM (secara daring dalam bentuk pamflet dengan memanfaatkan platforrm instagram) adalah agar masyarakat warga desa Cibodasari, dan masyarakat umum dapat mematuhi aturan PPKM.

\section{Hasil dan Pembahasan}

Kegiatan pengabdian kepada masyarakat ini bertujuan untuk meningkatkan kewasapadaan masyarakat Kelurahan Cibodasari terhadap Covid-19 pada masa PPKM. Kondisi masyarakat sebelum dilakukan kegiatan pengabdian kepada masyarakat berada pada kondisi Sebagian besar masyarakat Kelurahan Cibodasari banyak yang tidak peduli dengan pandemic Covid-19. Hal ini juga ditunjukkan bahwa masyarakat enggan untuk melaksanakan protocol kesehatan. Masyarakat enggan melaksanakan protocol kesehatan dikarenakan detidakpahaman tentang bahaya dari Covid-19. 


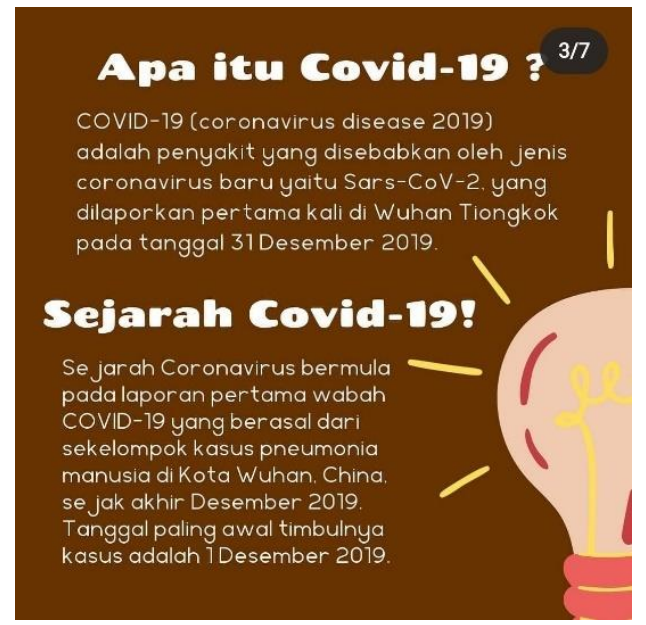

Gambar 1. Sosialisasi Covid-19 melalui Media Sosial

Kegiatan pertama yang dilakukan oleh tim pengabdian kepada masyarakat adalah melakukan sosialisasi Covid-19. Meskipun pandemic telah berjalan sekitar 1 tahun 6 bulan namun masih banyak masyarakat yang tidak peduli. Sosialisasi dilaksanakan melalui media sosial Instagram dan youtube. Tim pengabdian kepada masyarakat membuat flyer yang diunggah pada platform Instagram. Pada flyer tersebut menjelaskan tentang Covid-19 (coronavirus disease 2019) adalah penyakit yang disebabkan oleh jenis corona virus baru yaitu Sars-Cov-2 yang dilaporkan pertama kali di Wuhan Tiongkok pada tanggah 31 Desember 2019. Gejala dari pasien meliputi demam laise, batuk kering, dan dispnea yang didiagnosis sebagai gejala infeksi virus pneumonia. Awalnya penyakit itu disebut pneumonia Wuhan oleh pers karena gejala yang serupa pnemunia. Hasil Skrening genom menunjukkan bahwa agen penyebabnya adalah coronavirus baru. Organisasi Kesehatan (WHO) untuk sementara menamai virus baru 2019 novel coronavirus (2019nCov) pada 12 Januari 2020 dan mejadi corona =virus 2019 (Covid-19) pada 12 Februari 2020.

Penyakit Covid-19 yang disebabkan oleh virus sars-Cov2 atau yang dikenal juga dengan coronavirus penyebab wabah Severe Acute Respiratory Syndrome (Sars) dan Middle East Respiartory Syndrome (Mers). Ketiga wabah ini memiliki kecepatan infeksi yang berbeda dalam menjangkiti para korban. Diantara ketiganya Covid-19 adalah yang tercepat dalam mengakibatkan infeksi antar manusia. Covid-19 menjadi wabah dengan durasi penularan tercepat. Virus yang berkembang dari Wuhan, Tingkok ini hanya membutuhkan 48 hari untuk menginfeksi 1.000 orang pertama.

Sejak Covid-19 pertama kali muncul di Tiongkok, virus ini telah berkembang selama empat bulan dan dengan cepat menyebar ke negara lain di seluruh dunia sebagai ancaman global. Pada tanggal 11 Maret 2020, WHO akhirnya membuat penilaian bahwa Covid-19 dapat dikategorikan sebagai pandemic (Syakurah dan Moudy, 2020), menyusul flu Spanyol 1918 (H1N1), flu Asia 1957 (H2N2), flu Hongkong (H3N2). Dan flu Pandemi 2009 (H1N1) yang masing-masing menyebabkan sekitar 50juta, 1,5 juta , 1 juta dan 300.000 kematian manusia. Krisis Covid-19 saat ini tentu tidak akan jadi yang terakhir tetapi hal ini membuat manusia belajar banyak hal sekaligus memanfaatkan berbagai ilmu dan pengetahuan yang telah kita dapatkan dari sejarah Coronavirus ini, serta pengalaman untuk bertahan hidup dan bersiap bangkit kembali setelah wabah ini mereda.

Selain pengenalan pada Covid-19, sosialisasi juga mengingatkan masyarakat untuk disiplin menerapkan 5M (Susilowati, Nurkhalim \& Jayanti, 2021)., meliputi Memakai masker, Menjaga jarak, Mencuci tangan, menghindari kerumunan, dan Mengurangi kerumunan. Sosialisasi dilaksanakan melalui media sosial Instagram, dengan dibuat flyer yang menarik. Tim pengamdian kepada masyarakat juga menyajikan video bagaima mencuci tangan yang baik dan benar, sehingga kuman yang ada di tangan dapat berkurang. 

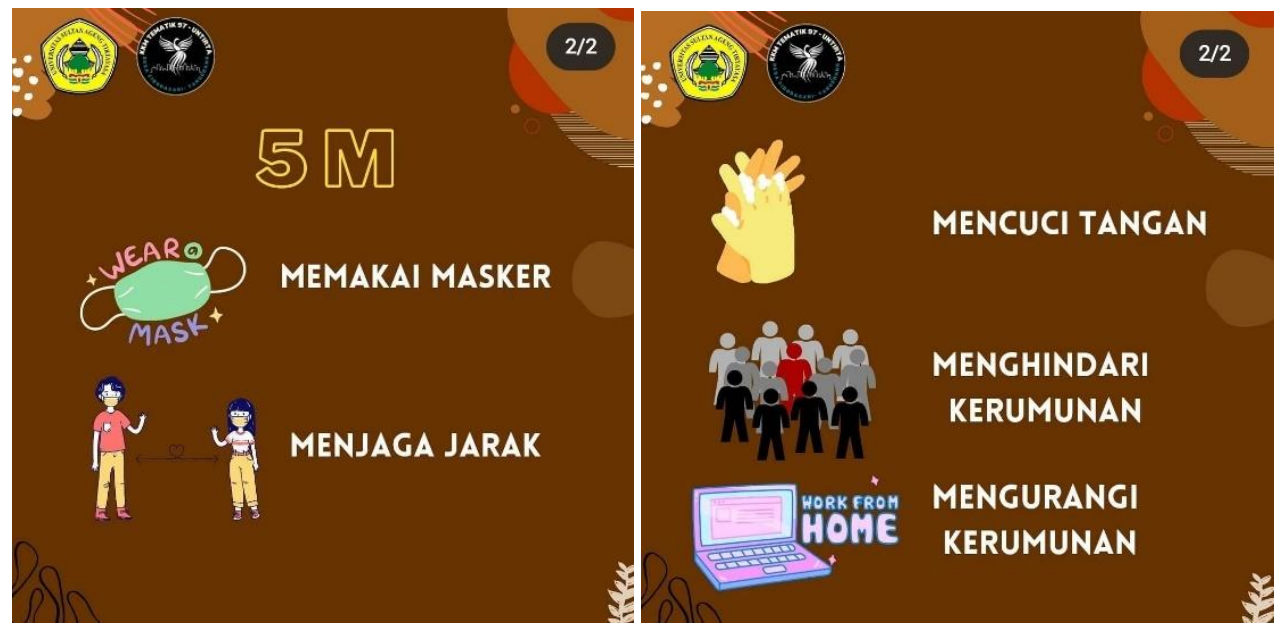

Gambar 2. Kampanye 5M melalui Media Sosial

Unggahan berupa flyer dan video (youtube) disebarkan kepada masyarakat Cibodasari melalui Whatsapp Group yang adapa pada kelompok masyarakat. Masyarakat dapat melihat unggahan berupa gambar dan video. Dari program Sosialisasi Covid-19, warga dan anak-anak Kelurahan Cibodasari serta masyarakat umum meningkatkan kesadaran dan mengingatkan kesesama untuk menerapkan protokol kesehatan dan menjaga pola hidup sehat agar terhindar dari hal-hal yang tidak diinginkan.

Selain sosialisai Covid-19, tim pengabdian kepada masyarakat juga melaksanakan kegiatan yaitu ikut serta pada kegiatan kelurahan berupa penyemprotan. Kelurahan Cibodasari merupakan salah satu kelurahan dengan tingkat infeksi Covid-19 yang tinggi di Kecamatan Cibodas. Sebagai salah satu upaya pemerintahan Kelurahan Cibodasari menekan infeksi Covid-19, Keluarahan bersama tim pengabdian kepada masyarakat Universitas Sultan Ageng Tiratayasa melakukan penyemprotan disinfektan.

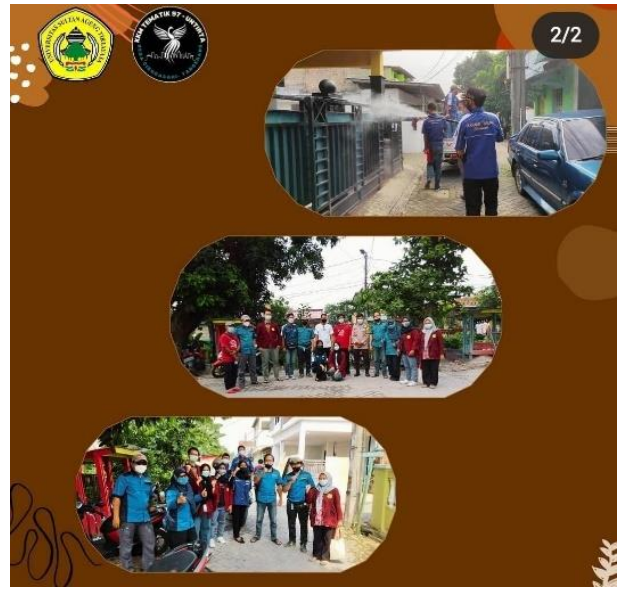

Gambar 3. Penyemprotan Disinfektan

Salah satu cara memutus rantai penularan Covid-19 adalah dengan menjaga kebersihan dengan membunuh virus Covid-19 sebelum ia menginfeksi manusia. Berbagai cara diantaranya adalah disinfektan yang disemprotkan atau diusapkan pada berbagai benda mati yang mungkin terpapar virus disinfektan (Churaez, Ramadani, Firmansyah, Mahmudah, \& Ramli, 2020). Disinfektan adalah bahan kimia yang digunakan untuk menghambat atau membunuh mikroorganisme (misalnya pada bakteri, virus dan jamur kecuali spora bakteri) pada permukaan benda mati, seperti 
furniture, ruangan, lantai, dan lain-lain. Disinfektan dapat digunakan untuk membersihkan permukaan benda dengan cara mengusapkan larutan disinfektan pada bagian yang terkontaminasi, misalnya pada lantai, dinding, permukaan meja, daun pintu, saklar listrik dan lain-lain. Penggunaan disinfektan dengan teknik spray atau fogging telah digunakan untuk mengendalikan jumlah antimikroba dan virus di ruangan yang berisiko tinggi. Pada ruangan yang sulit dijangkau biasanya digunakan sinar UV dengan panjang gelombang tertentu. Proses ini akan mencegah penularan mikroorganisma patogen dari permukaan benda ke manusia (Lululangi).

Penggunaan disinfektan yang tepat dapat mencegah penularan Covid-19. Usaha-usaha untuk melakukan disinfeksi yang dilakukan oleh Keluarahan Cibodasari perlu diapresiasi. Penyemprotan disinfektan di Kelurahan Cibodasari memperhatikan jumlah dan daerah yang disemprot, karena penyemprotan dilakukan untuk daerah yang memungkin dilakukan penyemprotan. Penyemprotan disinfektan Kelurahan Cibodasari meningkatkan pola hidup sehat dan dapat terciptanya lingkungan yang bersih aman dan sehat.

Selain melakukan sosialisasi tentang Covid-19 dan melakukan disinfektan, tim pengabdian kepada masyarakat melakukan sosialisasi Pemberlakuan Pembatasan Kegaitan Masyarakat (PPKM). Hal ini dilakukan sebagai bentuk dukungan terhadap program pemerintah pusat menekan penyebaran Covid-19. Berikut sejumlah aturan yang tercantum dalam Inmendagri Nomor 22 tahun 2021:

a. Pelaksanaan kegiatan belajar mengajar (sekolah, perguruan tinggi, akademi, tempat pendidikan/pelatihan) dilakukan secara daring/online.

b. Pelaksanaan kegiatan pada sektor non-esensial diberlakukan seratus persen work from home (WFH).

c. Pelaksanaan kegiatan pada sektor esensial seperti perbankan dapat beroperasi dengan kapasitas maksimal lima puluh persen staf untuk lokasi yang berkaitan dengan pelayanan kepada masyarakat, serta dua puluh lima persen untuk pelayanan administrasi perkantoran guna mendukung operasional.

d. Sektor esensial seperti pasar modal, teknologi komunikasi dan informasi, dan perhotelan, dapat beroperasi dengan kapasitas maksimal lima puluh persen staf.

e. Sektor esensial seperti industri orientasi ekspor dapat beroperasi dengan kapasitas maksimal lima puluh persen staf hanya di fasilitas produksi/pabrik, serta sepuluh persen untuk pelayanan adminsitrasi perkantoran.

f. Sektor kritikal khusus kesehatan dan keamanan dapat beroperasi dengan kapasitas 100 persen.

g. Sektor kritikal lainnya dapat beroperasi seratus persen maksimal staf, hanya pada fasilitas produksi/konstruksi/pelayanan kepada masyarakat, dan untuk pelayanan administrasi perkantoran guna mendukung operasional diberlakukan maksimal dua puluh lima persen staf.

h. Warung, restoran, kafe, dan usaha sejenis hanya melayani take away.

i. Mal, pusat perbelanjaan, dan usaha sejenis tutup, kecuali akses untuk restoran, supermarket, dan pasar swalayan.

j. Pelaksanaan kegiatan konstruksi untuk infrastruktur publik (tempat konstruksi dan lokasi proyek) beroperasi seratus persen.

k. Tempat ibadah tidak mengadakan peribadatan.

1. Fasilitas umum ditutup sementara.

m. Kegiatan seni, olahraga, dan sejenisnya, dilarang untuk dilakukan.

n. Transportasi umum maksimal mengangkut penumpang sebanyak 70 persen dari kapasitas normal.

o. Resepsi pernikahan dilarang. 

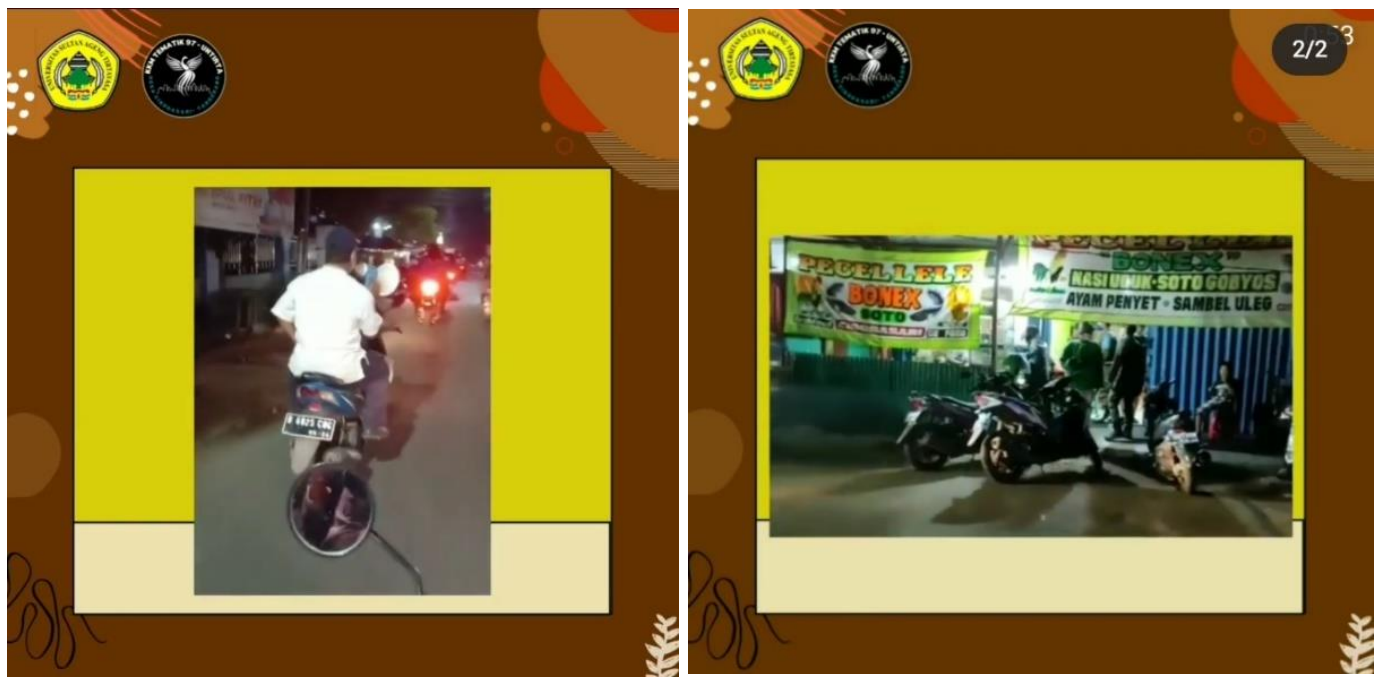

Gambar 4. Sosialisasi dan Penertiban Pemberlakuan Pembatasan Kegaitan Masyarakat

PPKM yang dilaksanakan pada tingkat kelurahan memberikan dampak penanganan Covid-19 tingkat Kota Tangerang. Salah satunya dapat diketahui dari Bed Occupancy Rate (BOR) rumah sakit yang mengalami penurunan menjadi $78 \%$, yang sebelumnya mencapai angka diatas $80 \%$. Walaupun BOR turun, warga Kelurahan Cibodasari tidak mengurangi kewaspadaan pada Covid-19 dan tetap penerapan protokol kesehatan.

Keseluruhan rangkaian kegiatan yang dilaksanakan oleh tim pengabdian kepada masyarakat Universitas Sultan Ageng Tirtayasa mendapatkan dukungan dari warga Kelurahan dan pemerintah Cibodasari yang kooperatif sehingga kegiatan bisa dilakukan dengan baik. Walaupun pada pelaksanaan program sosialisasi PPKM beberapa masyarakat kurang paham dan kurang mentaati aturan PPKM.

\section{Kesimpulan}

Tim pengabdian kepada masyarakat Universitas Sultan Ageng Tirtayasa bersama dengan Kelurahan Cibodasari melaksakan kegiatan untuk meningkatkan kewaspadaan masyarakat terhadap Covid-19 pada masa PPKM melalui tiga kegiatan, yaitu sosialisasi Covid-19, Penyemprotan disinfektan dan sosialisasi PPKM. Setelah kegiatan tersebut dilakukan masyarakat Kelurahan Cibodasari semakin patuh pada protocol kesehatan dan tingkat BOR pada Kota Tangerang menurun. Penurunan BOR pada Kota Tangerang salah satunya disebabkan oleh turunnya jumlah warga yang terkonfirmasi positif Covid-19. Namun demikian, warga Kelurahan Cibodasari tetap patuh protocol kesehatan dalam menjalankan kegiatan sehari-hari.

\section{Ucapan Terima Kasih}

Ucapan terima kasih disampaikan kepada Warga Kelurahan Cibodasari, Pemerintahan Kelurahan Cibodasari, dan Universitas Sultan Ageng Tirtayasa yang telah memberikan dukungan baik moril mapun materiil untuk melaksanakan kegiatan pengabdian kepada masyarakat.

\section{References}

Churaez, F. I., Ramadani, R., Firmansyah, R., Mahmudah, S. N., \& Ramli, S. W. (2020). Pembuatan Dan Penyemprotan Disinfektan: Kegiatan Kkn Edisi Covid-19 Di Desa Bringin, Malang. Sinergi: Jurnal Pengabdian, 2(2), 50-55 
Hadisaputro, Suharyo. 2021. Pakar Epidemiologi Undip: Titik Lengah Masyarakat Memicu Penularan Covid. https://www.undip.ac.id/post/19871/pakar-epidemiologi-undip-titik-lengah-masyarakat-memicu-penularancovid.html. Diakses tanggal 8 Agustus 2021.

Instruksi Menteri Dalam Negeri Nomor 22 Tahun 2021 tentang Tentang Pemberlakuan Pembatasan Kegiatan Masyarakat Level 4 Corona Virus Disease 2019 di Wilayah Jawa dan Bali.

Lululangi, M., \& Rizal, A. A. N. (2020). PKM Melalui Pelatihan Pembuatan Desinfektan untuk Mencegah Penyebaran Covid-19 di Kota Makassar. PENGABDI, 1(2).

Susilowati, I., Nurkhalim, R. F., \& Jayanti, K. D. (2021). Membudayakan Protokol Kesehatan Di Lingkungan Perumahan Demi Pengendalian Penyebaran Covid-19. Jurnal ABDINUS: Jurnal Pengabdian Nusantara, 5(1), 66-74.

Syakurah, R. A., \& Moudy, J. (2020). Pengetahuan terkait usaha pencegahan Coronavirus Disease (COVID-19) di Indonesia. HIGEIA (Journal of Public Health Research and Development), 4(3), 333-346. 